\title{
PENGARUH PERBEDAAN WAKTU APLIKASI PROBIOTIK TERHADAP KUALITAS AIR DAN SINTASAN PASCA LARVA UDANG WINDU (Penaeus monodon)
}

\author{
Muliani, Nurbaya, dan Muharijadi Atmomarsono \\ Balai Riset Perikanan Budidaya Air Payau \\ Jl. Makmur Dg. Sitakka, Maros, Sulawesi Selatan 90511 \\ E-mail: mulianim@yahoo.com
}

(Naskah diterima: 11 Mei 2009; Disetujui publikasi: 25 Januari 2010)

\begin{abstract}
ABSTRAK
Penelitian ditujukan untuk mengetahui pengaruh waktu pemberian probiotik yang berbeda terhadap perubahan kualitas air dan sintasan udang windu dalam skala laboratorium. Penelitian dilaksanakan di Laboratorium Basah Balai Riset Perikanan Budidaya Air Payau (BRPBAP), Maros menggunakan 21 buah akuarium berukuran $40 \mathrm{~cm}$ $\times 30 \mathrm{~cm} \times 27 \mathrm{~cm}$ yang diisi tanah tambak setebal $10 \mathrm{~cm}$ dan air laut salinitas $28 \mathrm{ppt}$ sebanyak $15 \mathrm{~L}$ serta 30 ekor pascalarva udang windu. Probiotik yang digunakan adalah kombinasi BL542+BT951+MY1112 dengan perlakuan; (A) aplikasi probiotik pada awal sampai akhir penelitian; (B) aplikasi probiotik pada minggu ke-Il sampai akhir penelitian; (C) aplikasi probiotik pada minggu ke-IV sampai akhir penelitian; (D) aplikasi probiotik pada minggu ke-VI sampai akhir penelitian; (E) aplikasi probiotik pada minggu ke-VIII sampai akhir penelitian; (F) aplikasi probiotik pada minggu ke $X$ sampai akhir penelitian; (G) kontrol (tanpa probiotik), masing-masing diulang 3 kali. Penelitian berlangsung selama 12 minggu. Pengamatan parameter kualitas air dilakukan setiap 2 minggu yang meliputi; total bakteri, total Vibrio spp., BOT, $\mathrm{NH}_{3}-\mathrm{N}, \mathrm{NO}_{2}-\mathrm{N}, \mathrm{NO}_{3}-\mathrm{N}, \mathrm{PO}_{4}-\mathrm{P}$. Sedangkan pengamatan sintasan udang windu dilakukan pada akhir penelitian. Hasil penelitian menunjukkan bahwa aplikasi probiotik pada minggu ke-IV dapat menekan konsentrasi BOT dan $\mathrm{NH}_{3}-\mathrm{N}$, menurunkan total Vibrio sp. sehingga berdampak kepada peningkatan sintasan udang windu.
\end{abstract}

KATA KUNCI: probiotik, kualitas air, sintasan, Penaeus monodon

ABSTRACT: The effect of different application time of probiotic on water quality and survival rate of tiger shrimp (Penaeus monodon) postlarvae. By: Muliani, Nurbaya, and Muharijadi Atmomarsono

The aim of this experiment was to study the effect of different application time of probiotic on water quality and survival rate of tiger shrimp postlarvae reared in laboratory scale. This experiment was conducted in the wet laboratory of the Research Institute for Coastal Aquaculture (RICA), Maros using 21 aquaria of $40 \mathrm{~cm} \times 30 \mathrm{~cm} \times$ $27 \mathrm{~cm}$ in size. Each aquarium was layered with $10 \mathrm{~cm}$ of pond sediment at the bottom, then filled with $15 \mathrm{~L}$ of $28 \mathrm{ppt}$ pond water, and stocked with 30 individual of tiger shrimp postlarvae. Probiotic bacteria used in this study were BL542+BT951+MY1112. Times of probiotic application were; (A) from the beginning to the end of the experiment; (B) from the second week to the end of the experiment; (C) from the fourth week to the end of the experiment; (D) from the sixth week to the end of the experiment; (E) from the eighth week to the end of the experiment; $(F)$ from the tenth week to the end of the experiment; $(G)$ control (without probiotic application). Each treatment was arranged 
in triplicate. The research lasted for 12 weeks. TOM (Total Organic Matter), $\mathrm{NH}_{3}-\mathrm{N}$, $\mathrm{NO}_{2}-\mathrm{N}, \mathrm{NO}_{3}-\mathrm{N}, \mathrm{PO}_{4}-\mathrm{P}$, total bacteria, and total Vibrio spp. were monitored weekly. Survival rate of the tiger shrimp larvae was measured at the end of the experiment. The result showed that application of probiotic from the fourth week to the end of the experiment decreased TOM and NH3-N concentrations, total Vibrio sp., and eventually increased tiger shrimp survival rate.

KEYWORDS: probiotic, water quality, survival rate, Penaeus monodon

\section{PENDAHULUAN}

Kasus penyakit pada budidaya udang beberapa tahun terakhir ini, melanda Indonesia dan negara-negara lain seperti Thailand (Pasharawipas et al., 1998; Ruangpan et al., 1998; Sukhumsirichart et al., 1998), Taiwan (Peng et al., 2001), Filipina (Albaladejo et al., 1998; Loh et al., 1998), India (Vaseeharan et al., 2003), Australia (Spann et al., 1995), Jepang (Kono et al., 2004), dan Amerika (Dhar et al., 2001), kini sedikit demi sedikit mulai dapat teratasi. Hal ini bukan karena penyakit virus sebagai penyebab utamanya yang dapat diatasi, akan tetapi terutama karena subtitusi dari udang windu ke vaname, meskipun pada kenyataannya bahwa udang vaname juga tidak terlepas dari serangan penyakit terutama WSSV (Rodriguez et al., 2003; SanchezMartinez et al., 2007). Penggunaan bakteri probiotik sebagai bakteri pengurai bahan organik juga memberikan kontribusi terhadap perbaikan lingkungan budidaya yang berefek pada peningkatan kesehatan udang sehingga tidak mudah stres dan terserang penyakit.

Perkembangan usaha budidaya di bidang perikanan memacu perkembangan penggunaan probiotik (Waston et al., 2008), baik melalui pakan maupun ditebar langsung dalam media budidaya. Hal ini juga memacu kegiatan ekplorasi bakteri-bakteri alam dari berbagai sumber yang potensial digunakan sebagai probiotik dan biokontrol. Beberapa sumber bakteri probiotik yang telah dikaji antara lain air laut dan sedimen (Muliani et al., 2003; Tjahjadi et al., 1994), koral (Radjasa et al., 2005), hatcheri (Rosa et al., 1997; Hala 1999; Haryanti et al., 2000), daun mangrove (Muliani et al., 2004), dan tambak udang (Muliani et al., 2006), dari seabream (Sparus aurata, L.) (Chabrillon et al., 2006), dari usus ikan-ikan lele (Sugita et al., 2007), dari ikan nila (Aly et al., 2008a), dari usus ikan (Balcazar et al., 2008).

Beberapa jenis bakteri yang biasa digunakan sebagai probiotik di antaranya
Bacillus sp., Basillus subtilis, Lactobacillus spp., Brevibacillus sp., Pseudomonas sp., Pseudoalteromonas sp., Pseudomona aeruginosa, Vibrio alginolyticus, Vibrio carcarie, dan lain-lain. Penggunaan bakteri probiotik sudah sangat meluas di hampir semua kegiatan budidaya diantaranya, pemeliharaan larva kepiting (Nogami \& Maeda, 1992), larva rajungan (Susanto et al., 2005), dan budidaya artemia (Villamil et al., 2003). Pada budidaya ikan, penggunaan probiotik dijumpai pada pemeliharaan rainbow trout (Brunt \& Austin, 2005; Brunt et al., 2007), ikan karper (Labeo rohita) (Kumar et al., 2006; Banerjee et al., 2007), pematangan gonad ikan hias (Ghosh et al., 2007), pemeliharaan ikan nila (Tilapia nilotica) (Aly et al., 2008a, Wang et al., 2008), larva ikan sebelah (flatfish) Senegalese sole (Makridis et al., 2008), larva gilthead sea bream (Sparus aurata, L) (Suzer et al., 2008), dan budidaya ikan kakap putih (seabass) (Rengpipat et al. 2008). Macey \& Coyne (2005), melaporkan penggunaan bakteri probiotik pada budidaya abalon. Penggunaan probiotik pada budidaya udang juga telah banyak dilaporkan, seperti pada budidaya udang windu (Meunpol et al., 2003; Vaseeharan \& Ramasamy, 2003; Vaseeharan et al., 2004; Lio-Po et al., 2005; Gunarto et al., 2006a,2006b; Vijayan et al., 2006), budidaya udang Penaeus chinensis (Li et al., 2006), budidaya udang vanamei (udang putih) (Nejad et al., 2006), budidaya udang galah (Keysami et al., 2007), pemeliharaan larva udang (Decamp et al., 2008), dan budidaya udang stylorostris (udang putih) (Castex et al., 2008).

Berkat penggunaan probiotik, maka tidak sedikit pembudidaya yang meraup keuntungan besar karena hasil panen udang yang melimpah, namun sebaliknya banyak juga mengalami kerugian yang tidak sedikit akibat kegagalan panen meskipun telah menggunakan probiotik. Hal ini disebabkan oleh beberapa hal di antaranya, jenis, dosis, dan cara aplikasi probiotik yang kurang tepat. Beberapa tahun terakhir ini Balai Riset 
Perikanan Budidaya Air Payau (BRPBAP) telah mengembangkan pengunaan probiotik yang diisolasi dari laut, mangrove, maupun tambak. Probiotik ini diharapkan dapat berperan lebih aktif terhadap perbaikan lingkungan budidaya. Beberapa kajian terhadap probiotik tersebut telah dilakukan, seperti komposisi jenis (Nurbaya et al., 2007a; 2007b), jenis dan kepadatan probiotik (Muliani et al., 2007), pergiliran pemberian probiotik (Muliani et al., 2008a), dan rasio jenis bakteri probiotik (Muliani et al., 2008b). Aspek lain yang sangat penting untuk diketahui dalam penggunaan probiotik adalah waktu pemberian probiotik yang efektif, hal ini berkaitan erat dengan efisiensi biaya dan saat penumpukan bahan organik di dasar tambak. Jika probiotik terlalu cepat diberikan, sementara konsentrasi bahan organik di dasar tambak masih rendah, maka penggunaan probiotik tidak efisien dan akan menambah biaya operasional. Sebaliknya jika probiotik terlambat diberikan maka penumpukan bahan organik di dasar tambak akan memicu berkembangnya organisme patogen yang dapat membahayakan hewan budidaya. Berdasarkan hal tersebut maka dilakukan penelitian untuk mengetahui waktu yang efektif untuk pemberian probiotik yang dilakukan dalam skala laboratorium yang akan menjadi dasar nantinya untuk pengembangan di lapangan.

\section{BAHAN DAN METODE}

\section{Waktu dan Tempat}

Penelitian dilakukan di Laboratorium Kesehatan Ikan dan Lingkungan, Balai Riset Perikanan Budidaya Air Payau (BRPBAP), Maros mulai Juli sampai dengan Oktober 2008 menggunakan akuarium yang berukuran $40 \mathrm{~cm}$ $\times 30 \mathrm{~cm} \times 27 \mathrm{~cm}$ yang diisi air tambak sebanyak $15 \mathrm{~L}$. Hewan uji yang digunakan berupa benur windu PL 22 sebanyak 30 ekor/wadah yang sebelumnya telah dilakukan pengecekan bebas WSSV dengan PCR.

\section{Perlakuan dan Rancangan}

Penelitian menggunakan Rancangan Acak Lengkap (RAL) dengan perlakuan beda waktu aplikasi probiotik. Probiotik yang digunakan adalah kombinasi BL542+ BT951+MY1112 dengan perlakuan; (A) aplikasi probiotik pada awal sampai akhir penelitian; (B) aplikasi probiotik pada minggu ke-ll sampai akhir penelitian; (C) aplikasi probiotik pada minggu
ke-IV sampai akhir penelitian; (D) aplikasi probiotik pada minggu ke-VI sampai akhir penelitian; (E) aplikasi probiotik pada minggu ke-VIII sampai akhir penelitian; (F) aplikasi probiotik pada minggu ke-X sampai akhir penelitian; dan (G) kontrol (tanpa probiotik). Masing-masing perlakuan diulang 3 kali. Pengamatan parameter kualitas air dilakukan setiap 2 minggu yang meliputi BOT (bahan organik total), $\mathrm{NH}_{4}-\mathrm{N}, \mathrm{NO}_{2}-\mathrm{N}, \mathrm{NO}_{3}-\mathrm{N}$, dan $\mathrm{PO}_{4}-\mathrm{P}$ dalam air. Total bakteri dan total Vibrio spp. dalam air dan sedimen juga diamati 2 kali seminggu, sedangkan pengamatan sintasan udang dilakukan pada akhir penelitian.

\section{Analisis Data}

Data sintasan udang windu yang diperoleh dianalisis ragam dan dilanjutkan dengan uji Beda Nyata Terkecil (Steel \& Torrie, 1981). Sedangkan data kualitas air dan bakteri dianalisis secara deskriptif dalam bentuk tabel dan grafik, dan hanya data pada akhir penelitian yang dianalisis ragam dan dilanjutkan dengan uji Beda Nyata Terkecil (Steel \& Torrie, 1981).

\section{HASIL DAN BAHASAN}

\section{Peubah Kualitas Air}

\section{BOT}

Konsentrasi BOT selama penelitian disajikan pada Gambar 1A. Pada gambar tersebut terlihat bahwa konsentrasi BOT dari awal hingga minggu keempat mengalami peningkatan dan selanjutnya cenderung stabil hingga minggu ke-12 (akhir penelitian), kecuali pada perlakuan $D$ yang mengalami penurunan pada minggu keenam dan naik kembali pada minggu kedelapan dan stabil hingga minggu ke-12 (akhir penelitian). Namun demikian ada kecenderungan bahwa konsentrasi BOT pada perlakuan $\mathrm{C}$ lebih rendah dibanding perlakuan lainnya dari awal hingga minggu ke-10. Pada minggu ke-12 (akhir penelitian) konsentrasi BOT terendah pada perlakuan $\mathrm{F}$ (pemberian probiotik pada minggu ke-10) dan tertinggi pada kontrol (tanpa pemberian probiotik) dan secara statistik keduanya berbeda nyata $(P<0,05)$, namun tidak berbeda nyata $(P>0,05)$ dengan perlakuan lainnya. Gunarto et al. (2006a) melaporkan, bahwa konsentrasi BOT pada tambak yang menggunakan probiotik komersil berkisar 7,05-14,8 mg/L, sedangkan yang tidak menggunakan probiotik berkisar 8,4- 

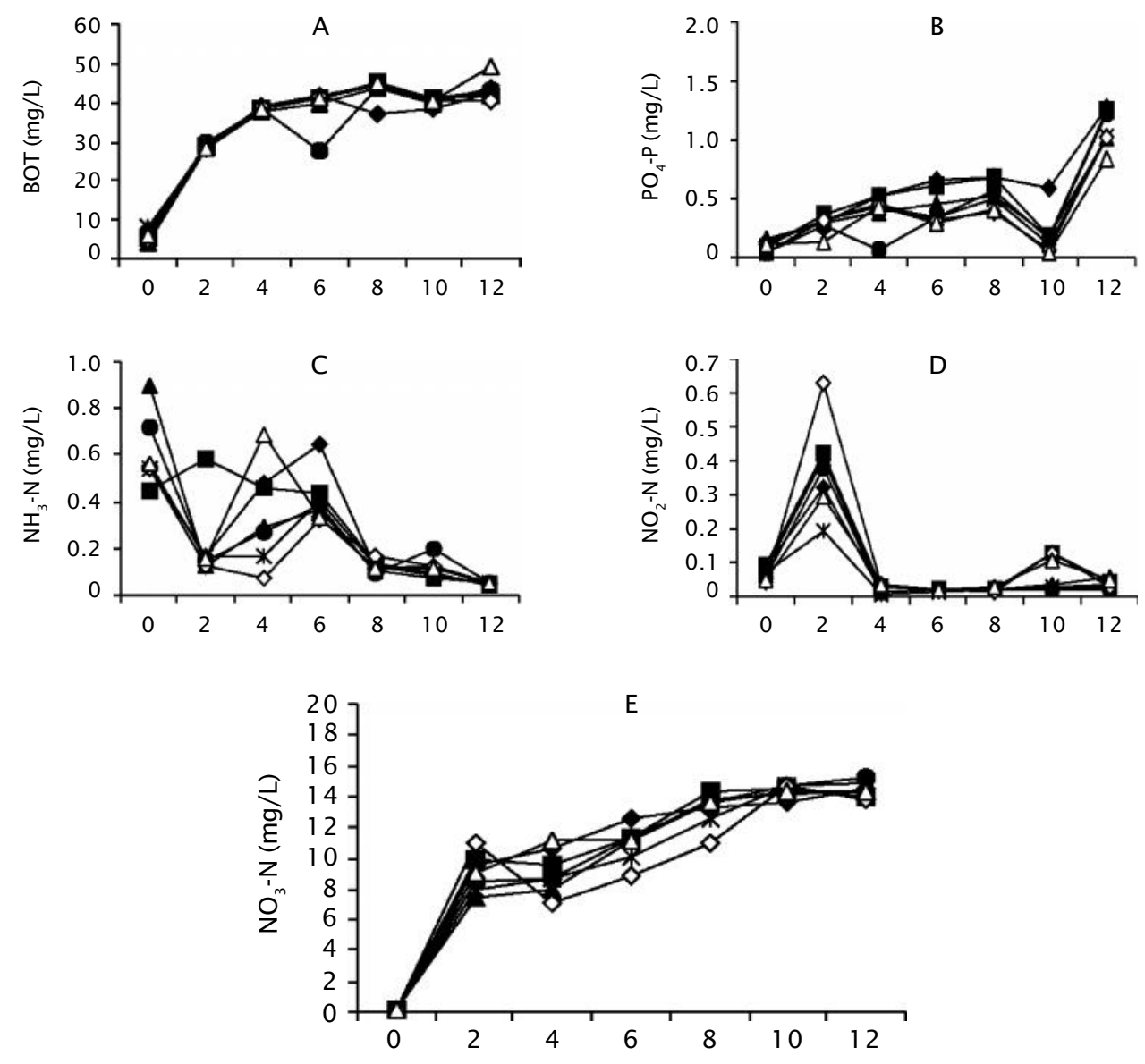

Waktu pengamatan (minggu)/Sampling times (week)

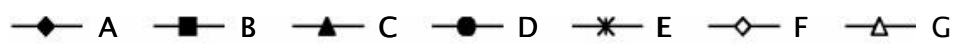

Keterangan (Notes):

(A) Aplikasi probiotik pada awal sampai akhir penelitian (Probiotic was applied from the beginning to the end of the experiment)

(B) Aplikasi probiotik pada minggu ke-Il sampai akhir penelitian (Probiotic was applied from the second week to the end of the experiment)

(C) Aplikasi probiotik pada minggu ke-IV sampai akhir penelitian (Probiotic was applied from the fourth week to the end of the experiment)

(D) Aplikasi probiotik pada minggu ke-VI sampai akhir penelitian (Probiotic was applied from the sixth week to the end of the experiment)

(E) Aplikasi probiotik pada minggu ke-VIII sampai akhir penelitian (Probiotic was applied from the eighth weeks to the end of the experiment)

(F) Aplikasi probiotik pada minggu ke-X sampai akhir penelitian (Probiotic was applied from the teenth week to the end of the experiment)

(G) Kontrol/tanpa probiotik (Control/without probiotic application)

Gambar 1. Konsentrasi BOT (A), $\mathrm{PO}_{4}-\mathrm{P}(\mathrm{B}), \mathrm{NH}_{3}-\mathrm{N}(\mathrm{C}), \mathrm{NO}_{2}-\mathrm{N}(\mathrm{D})$, dan $\mathrm{NO}_{3}-\mathrm{N}(\mathrm{E})(\mathrm{mg} / \mathrm{L})$ dalam air pemeliharaan pascalarva udang windu selama penelitian

Figure 1. Concentration of total organik matter (A), $\mathrm{PO}_{4}-\mathrm{P}(\mathrm{B}), \mathrm{NH}_{3}-\mathrm{N}(C), \mathrm{NO}_{2}-\mathrm{N}(D)$, and $\mathrm{NO}_{3}-\mathrm{N}(\mathrm{E})(\mathrm{mg} / \mathrm{L})$ in the rearing media of tiger shrimp postlarvae during the experiment 
$17,0 \mathrm{mg} / \mathrm{L}$. Konsentrasi BOT pada penelitian ini jauh lebih rendah dibanding dengan hasil penelitian sebelumnya dengan menggunakan bakteri yang sama tetapi tidak dikombinasikan (Muliani et al., 2005). Akan tetapi relatif sama dengan hasil penelitian yang menggunakan probiotik yang diisolasi dari laut, mangrove dan tambak dengan kombinasi jenis dan kepadatan yang berbeda, di mana konsentrasi BOT berkisar antara 11,0-20,7 mg/L (Muliani et al., 2007).

$\mathrm{PO}_{4}-\mathrm{P}$

Konsentrasi $\mathrm{PO}_{4}-\mathrm{P}$ selama penelitian disajikan pada Gambar 1B. Pada gambar tersebut terlihat bahwa konsentrasi $\mathrm{PO}_{4}-\mathrm{P}$ dari awal hingga minggu kedelapan mengalami peningkatan yang sangat kecil. Setelah memasuki minggu ke-10, konsentrasi $\mathrm{PO}_{4}-\mathrm{P}$ pada beberapa perlakuan mengalami penurunan, dan pada perlakuan lainya relatif stabil. Peningkatan konsentrasi $\mathrm{PO}_{4}-\mathrm{P}$ yang cukup signifikan pada semua perlakuan terjadi pada minggu ke-12 (akhir penelitian), terutama pada perlakuan A, B, dan D. Pada akhir penelitian konsentrasi $\mathrm{PO}_{4}-\mathrm{P}$ tertinggi pada perlakuan A yaitu $1,2807 \mathrm{mg} / \mathrm{L}$ dan terendah pada kontrol yaitu $0,8507 \mathrm{mg} / \mathrm{L}$. Konsentrasi $\mathrm{PO}_{4}-\mathrm{P}$ pada penelitian ini relatif lebih tinggi dibanding konsentrasi $\mathrm{PO}_{4}-\mathrm{P}$ pada penelitian sebelumnya yang menggunakan rasio bakteri probiotik yaitu berkisar antara $0,29843 \mathrm{mg} / \mathrm{L}$ pada perlakuan O (BL536, BL542 104 $\mathrm{cfu} / \mathrm{mL}+$ BR931, MY1112104 cfu/mL + MR55,BT951104 $\mathrm{cfu} / \mathrm{mL}$ ) sampai dengan $0,3823 \mathrm{mg} / \mathrm{L}$ pada perlakuan M (BL536, BL542 $10^{2} \mathrm{cfu} / \mathrm{mL}+$ BR931, MY1112102 cfu/mL + MR55,BT951 104 $\mathrm{cfu} / \mathrm{mL}$ ) (Muliani et al., 2008a). Hasil analisis statistik menunjukkan bahwa konsentrasi $\mathrm{PO}_{4}^{-}$ $P$ pada akhir penelitian pada $A, B$, dan $D$ berbeda nyata $(P<0,05)$ dengan kontrol, namun tidak berbeda nyata $(P>0,05)$ dengan perlakuan lainnya.

\section{$\mathrm{NH}_{4}-\mathrm{N}$}

Konsentrasi $\mathrm{NH}_{4}-\mathrm{N}$ selama penelitian disajikan pada Gambar 1C. Pada gambar tersebut terlihat bahwa konsentrasi $\mathrm{NH}_{4}-\mathrm{N}$ mengalami penurunan yang sangat drastis dari awal penelitian hingga minggu kedua terutama pada perlakuan $\mathrm{C}$ meskipun pada perlakuan ini probiotik baru diaplikasikan setelah minggu ke-IV. Meskipun konsentrasi $\mathrm{NH}_{4}-\mathrm{N}$ mengalami peningkatan pada minggu keempat dan keenam, namun pada perlakuan $\mathrm{C}$, konsentrasi
$\mathrm{NH}_{4}-\mathrm{N}$ relatif lebih rendah terutama setelah memasuki minggu ke-VIII dan ke-X. Sedangkan pada perlakuan $\mathrm{B}$, konsentrasi $\mathrm{NH}_{4}-\mathrm{N}$ relatif stabil dari awal hingga minggu kedua, kemudian menurun hingga akhir penelitian yaitu $0,0404 \mathrm{mg} / \mathrm{L}$. Konsentrasi $\mathrm{NH}_{4}-\mathrm{N}$ pada penelitian ini jauh lebih rendah dibanding penelitian sebelumnya yang menggunakan rasio bakteri probiotik yang berbeda yaitu antara $0,1770 \mathrm{mg} / \mathrm{L}$ pada perlakuan S sampai dengan $0,3393 \mathrm{mg} / \mathrm{L}$ pada kontrol (Muliani et al., 2008a). Hasil uji statistik menunjukkan bahwa tidak terdapat perbedaan yang nyata $(P>0,05)$ terhadap konsentrasi $\mathrm{NH}_{4}-\mathrm{N}$ pada semua perlakuan.

\section{$\mathrm{NO}_{2}-\mathrm{N}$}

Konsentrasi $\mathrm{NO}_{2}-\mathrm{N}$ selama penelitian dapat dilihat pada Gambar 1D. Dari gambar tersebut dapat diketahui bahwa konsentrasi $\mathrm{NO}_{2}-\mathrm{N}$ mengalami peningkatan dari awal hingga memasuki minggu kedua. Setelah minggu keempat konsentrasi $\mathrm{NO}_{2}-\mathrm{N}$ kembali menurun dan stabil hingga akhir penelitian. Pada saat itu konsentrasi $\mathrm{NO}_{2}-\mathrm{N}$ tertinggi pada perlakuan $\mathrm{C}$ (pemberian pada minggu ke-IV sampai akhir penelitian) yaitu $0,0575 \mathrm{mg} / \mathrm{L}$ dan terendah pada perlakuan D yaitu $0.0228 \mathrm{mg} / \mathrm{L}$. Konsentrasi $\mathrm{NO}_{2}-\mathrm{N}$ pada penelitian ini jauh lebih rendah dibanding hasil penelitian sebelumnya yang menggunakan probiotik dengan komposisi jenis dan kepadatan yang berbeda yaitu berkisar antara 0,2933-1,6141 mg/L (Muliani et al., 2007). Demikian juga yang menggunakan probiotik tunggal yaitu berkisar antara $0,2390 \mathrm{mg} / \mathrm{L}$ pada perlakuan yang menggunakan probiotik BL542 sampai dengan $0,2670 \mathrm{mg} / \mathrm{L}$ pada perlakuan yang menggunakan probiotik BR931 (Muliani et al., 2008b). Hasil analisis statistik menunjukkan bahwa konsentrasi $\mathrm{NO}_{2}-\mathrm{N}$ pada perlakuan $\mathrm{C}$ berbeda nyata $(P<0.05)$ dengan konsentrasi $\mathrm{NO}_{2}-\mathrm{N}$ pada perlakuan $\mathrm{D}, \mathrm{E}$, dan $\mathrm{F}$, namun tidak berbeda nyata $(P>0,05)$ dengan perlakuan lainnya. Hal ini menunjukkan bahwa pemberian bakteri probiotik yang dimulai pada minggu keIV dapat menurunkan konsentrasi $\mathrm{NO}_{2}-\mathrm{N}$ lebih baik dibandingkan pemberian probiotik yang dimulai pada minggu ke-VI, minggu ke-VIII , dan minggu ke-X.

$\mathrm{NO}_{3}-\mathrm{N}$

Konsentrasi $\mathrm{NO}_{3}-\mathrm{N}$ disajikan pada Gambar 1E. Pada gambar tersebut terlihat bahwa konsentrasi $\mathrm{NO}_{3}-\mathrm{N}$ selama penelitian 
mengalami peningkatan, kecuali pada perlakuan $\mathrm{F}$ yang mengalami peningkatan pada minggu kedua tapi kembali menurun pada minggu keempat. Namun demikian konsentrasi $\mathrm{NO}_{3}-\mathrm{N}$ pada perlakuan tersebut kembali meningkat pada minggu berikutnya. Dari minggu kedua hingga minggu ke-12 (akhir penelitian), konsentrasi $\mathrm{NO}_{3}-\mathrm{N}$ pada semua perlakuan relatif stabil. Konsentrasi $\mathrm{NO}_{3}-\mathrm{N}$ pada akhir penelitian tertinggi pada perlakuan D yaitu $15,249 \mathrm{mg} / \mathrm{L}$ dan terendah pada perlakuan $\mathrm{F}$ yaitu 13,800 mg/L. Konsentrasi $\mathrm{NO}_{3}-\mathrm{N}$ pada penelitian ini jauh lebih tinggi dibanding pada penelitian sebelumnya yaitu penggunaan probiotik secara tunggal yaitu $1,3006 \mathrm{mg} / \mathrm{L}$ pada perlakuan yang menggunakan isolat MY1112 dan 2,2037 mg/L pada perlakuan yang menggunakan isolat MR55 (Muliani et al., 2008b). Hasil analisis statistik menunjukkan bahwa tidak terdapat perbedaan yang nyata $(P>0,05)$ terhadap konsentrasi $\mathrm{NO}_{3}-\mathrm{N}$ antar semua perlakuan.

\section{Populasi Bakteri}

\section{Total bakteri dalam air dan sedimen}

Total bakteri dalam air selama penelitian disajikan pada Gambar 2A. Pada gambar tersebut terlihat bahwa total bakteri mengalami penurunan dari awal hingga memasuki minggu kedua. Dari minggu kedua hingga minggu ke10 total bakteri dalam air relatif stabil dan kembali mengalami kenaikan pada minggu ke12 (akhir penelitian), meskipun peningkatan tersebut tidak terlalu signifikan. Pada akhir penelitian total bakteri tertinggi pada perlakuan $\mathrm{C}$ (pemberian pada minggu ke-IV sampai akhir penelitian) yaitu $8,32 \times 10^{9} \mathrm{CFU} /$ $\mathrm{mL}$ dan terendah pada perlakuan $\mathrm{G}$ (kontrol) yaitu $2,88 \times 10^{8} \mathrm{CFU} / \mathrm{mL}$. Hasil analisis statistik menunjukkan bahwa pada akhir penelitian total bakteri dalam air pada perlakuan $C$ berbeda nyata $(P<0,05)$ dengan perlakuan $D$ dan $G$ (kontrol) dan tidak berbeda nyata $(P>0,05)$ dengan perlakuan lainnya.

Adapun total bakteri dalam sedimen dapat dilihat pada Gambar 2B. Pada gambar tersebut terlihat bahwa total bakteri dalam sedimen dari awal hingga minggu keenam mengalami kenaikan namun kenaikan tersebut sangat kecil. Setelah memasuki minggu kedelapan total bakteri cenderung stabil hingga akhir penelitian dan tertinggi pada perlakuan A dan terendah pada perlakuan F. Hasil analisa statistik menunjukkan bahwa total bakteri dalam sedimen pada akhir penelitian pada perlakuan $A$ berbeda nyata $(P<0,05)$ dengan perlakuan $F$ tetapi tidak berbeda nyata $(P>0,05)$ dengan perlakuan lainnya.

Penelitian sebelumnya dengan probiotik yang sama dengan komposisi dan kepadatan yang berbeda, total bakteri pada air pemeliharaan udang windu tertinggi yaitu 3,1 $\times 10^{8} \mathrm{CFU} / \mathrm{mL}$ (Muliani et al., 2007), sedangkan pada penggunaan probiotik dengan rasio yang berbeda tertinggi adalah $1,51 \times 10^{8} \mathrm{CFU} / \mathrm{mL}$ (Muliani et al., 2008a). Total bakteri pada air pemeliharaan nauplius di hatcheri, mysis di bak, dan postlarva di tambak pembesaran udang putih (Fenneropenaeus indicus) tidak berbeda nyata antara yang menggunakan probiotik komersil dari jenis Bacillus spp. dengan kontrol (tanpa penggunaan Bacillus spp.) (Nejad et al., 2006). Pada penggunaan probiotik komersil di tambak dilaporkan bahwa total bakteri pada air dan sedimen masing-masing berkisar antara $1,2 \times 10^{4}-5,5 \times 10^{5} \mathrm{CFU} / \mathrm{mL}$ dan $1,20 \times 10^{6}$. $1,0 \times 10^{7} \mathrm{CFU} / \mathrm{g}$ (Gunarto et al., 2006a). Devaraja et al. (2002) melaporkan bahwa total bakteri pada air dan sedimen tambak yang menggunakan probiotik komersil produk 1 masingmasing $5,40 \times 10^{3}-1,78 \times 10^{4} \mathrm{CFU} / \mathrm{mL}$ dan $2,70 \times 10^{5}-1,24 \times 10^{6} \mathrm{CFU} / \mathrm{g}$. Sedangkan yang menggunakan bakteri probiotik komersil produk 2 , total bakteri pada air dan sedimen masing-masing $2,48 \times 10^{4}-6,82 \times 10^{4} \mathrm{CFU} / \mathrm{mL}$ dan $5,60 \times 10^{5}-1,06 \times 10^{6} \mathrm{CFU} / \mathrm{g}$. Hal ini menunjukkan bahwa total bakteri pada penggunaan probiotik dalam penelitian ini relatif lebih tinggi dibandingkan dengan penggunaan probiotik komersil yang dilakukan di tambak. Ini menunjukkan bahwa probiotik yang digunakan berkembang dengan baik atau merangsang perkembangan bakteri alam yang telah ada dalam wadah penelitian lebih baik dibanding probiotik komersil yang digunakan di tambak. Menurut Poernomo (2004), bahwa probiotik yang diaplikasikan ke dalam tambak harus mampu hidup di dalam tambak, mampu tumbuh, berkembang biak, dan mampu berfungsi aktif pada bidang masing-masing sesuai yang diharapkan.

\section{Total Vibrio spp. dalam air dan sedimen}

Total Vibrio spp. dalam air selama penelitian disajikan pada Gambar 2C. Pada gambar tersebut terlihat total bakteri Vibrio spp. dalam air berfluktuasi dari awal hingga akhir 
penelitian. Pada minggu kedua total Vibrio spp. pada beberapa perlakuan mengalami penurunan, namun ada juga yang mengalami kenaikan yaitu terjadi pada perlakuan $A$ (pemberian probiotik pada awal sampai akhir penelitian), sedang pada perlakuan $F$ (pemberian pada minggu ke-X sampai akhir penelitian) relatif stabil. Penurunan yang signifikan terjadi pada minggu kedelapan, hal ini terjadi pada semua perlakuan, kecuali pada
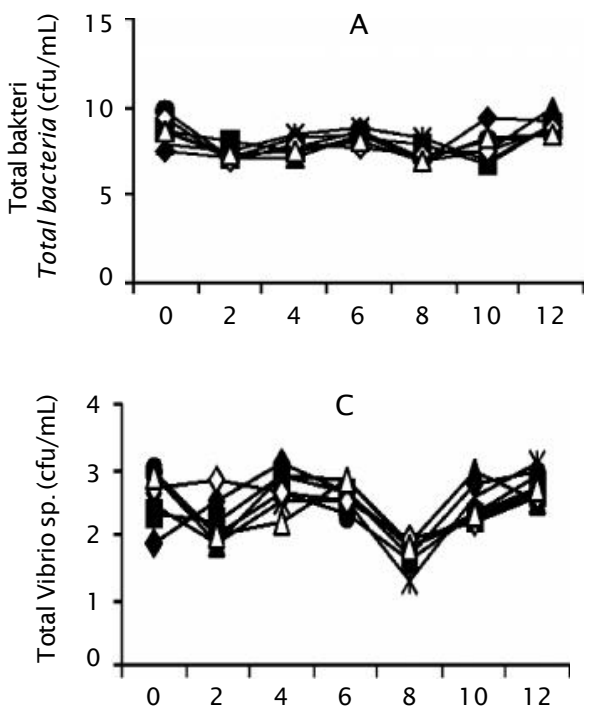

perlakuan $\mathrm{F}$ yang penurunan sangat kecil karena memang pada perlakuan ini probiotik baru diaplikasikan pada minggu ke-X. Penurunan tertinggi terjadi pada perlakuan $E$ (pemberian probiotik pada minggu ke-VII). Memasuki minggu ke-10 total Vibrio spp. dalam air kembali meningkat dan terus meningkat hingga minggu ke-12 (akhir penelitian) kecuali pada perlakuan $C$ (pemberian pada minggu keIV sampai akhir penelitian) yang mengalami
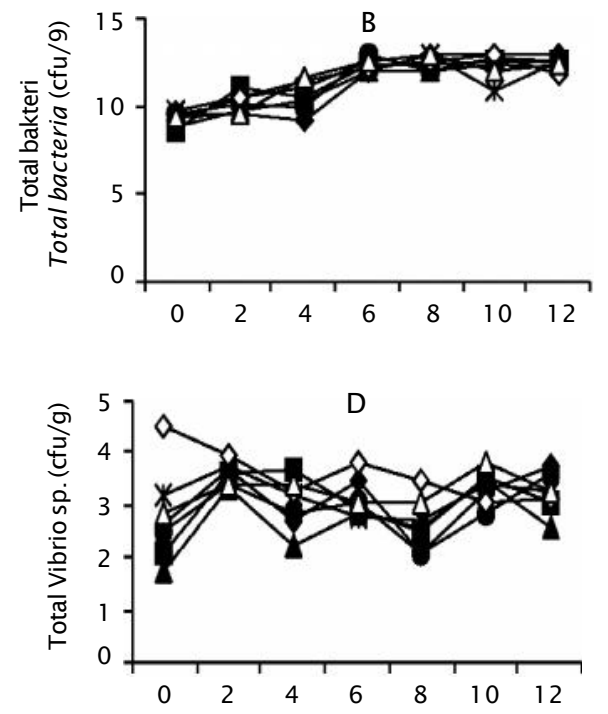

Waktu pengamatan (minggu) / Sampling times (week)

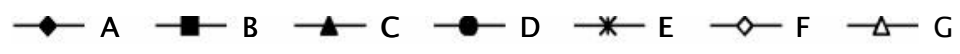

Keterangan (Notes):

(A) Aplikasi probiotik pada awal sampai akhir penelitian (Probiotic was applied from the beginning to the end of the experiment)

(B) Aplikasi probiotik pada minggu ke-II sampai akhir penelitian (Probiotic was applied from the second week to the end of the experiment)

(C) Aplikasi probiotik pada minggu ke-IV sampai akhir penelitian (Probiotic was applied from the fourth week to the end of the experiment)

(D) Aplikasi probiotik pada minggu ke-VI sampai akhir penelitian (Probiotic was applied from the sixth week to the end of the experiment)

(E) Aplikasi probiotik pada minggu ke-VIII sampai akhir penelitian (Probiotic was applied from the eighth weeks to the end of the experiment)

(F) Aplikasi probiotik pada minggu ke-X sampai akhir penelitian (Probiotic was applied from the teenth week to the end of the experiment)

(G) Kontrol/tanpa probiotik (Control/without probiotic application)

Gambar 2. (A) Total bakteri dalam air pemeliharaan (CFU/mL), (B) Total bakteri dalam sedimen (CFU/g), (C) Total Vibrio spp. dalam air pemeliharaan (CFU/mL), dan (D) Total Vibrio spp. dalam sedimen (CFU/g) selama penelitian

Figure 2. (A) Total bacteria in the rearing media (CFU/mL), (B) Total bacteria in the sediment (CFU/g), (C) Total Vibrio sp. in the rearing media (CFU/mL), and (D) Total Vibrio sp. in the sediment (CFU/g) during the experiment 
penurunan, meskipun secara statistik tidak berbeda nyata $(P>0,05)$ terhadap perlakuan lainnya.

Total Vibrio spp. dalam sedimen selama penelitian dapat dilihat pada Gambar 2D. Seperti halnya total Vibrio spp. dalam air, total Vibrio spp. dalam sedimen juga berfluktuasi dari awal hingga akhir penelitian. Pada minggu kedua mengalami peningkatan, namun kembali menurun setelah memasuki minggu keempat meskipun tidak pada semua perlakuan karena ada perlakuan yang justru mengalami kenaikan. Perlakuan $\mathrm{F}$ memperlihatkan pola yang lain dari perlakuan lainnya, karena dari awal hingga akhir penelitian total Vibrio spp. pada perlakuan tersebut cenderung mengalami penurunan meskipun sempat mengalami kenaikan pada minggu keenam, namun kembali menurun pada minggu ketujuh hingga akhir penelitian. Pada akhir penelitian, konsentrasi Vibrio spp. terendah pada perlakuan $\mathrm{C}$ (pemberian pada minggu ke-IV sampai akhir penelitian), namun demikian secara statistik tidak berbeda nyata $(P>0,05)$ dengan perlakuan lainnya.

Kecenderungan rendahnya populasi Vibrio spp. dalam air dan sedimen pada perlakuan yang diberi probiotik mulai minggu ke-IV disebabkan penekanan oleh bakteri probiotik yang digunakan, dimana pada perlakuan tersebut total bakteri justru cenderung lebih tinggi baik dalam air maupun dalam sedimen. Hal ini berarti bahwa probiotik yang digunakan berkembang dengan baik dan menyebabkan terjadinya penekanan pada populasi Vibrio spp. baik dalam air maupun dalam sedimen. Hasil uji tantang secara In Vitro yang dilakukan oleh Banerjee et al. (2007), menunjukkan bahwa probiotik dari Bacillus sp. dapat menurunkan populasi $V$. alginolyticus VaM1 1 dan $V$. parahaemolyticus $\mathrm{VpM} 1$ dari $10^{8}$ menjadi $10^{2}$ $\mathrm{CFU} / \mathrm{mL}$.

\section{Sintasan Udang Windu}

Sintasan udang windu pada akhir penelitian disajikan pada Tabel 1. Pada tabel tersebut terlihat bahwa sintasan udang windu tertinggi pada perlakuan $C$ (pemberian probiotik pada minggu ke-IV sampai akhir penelitian) yaitu $70 \%$ disusul oleh perlakuan B (pemberian pada minggu ke-II sampai akhir penelitian) yaitu $66,7 \%$ dan terendah pada perlakuan G (kontrol) yaitu 34,6\%. Pada penelitian sebelumnya yang menggunakan rasio bakteri probiotik dalam skala laboratorium, sintasan pascalarva udang

Tabel 1. Sintasan udang windu (\%) pada akhir penelitian dengan perbedaan waktu aplikasi probiotik

Table 1. Survival rate (\%) of black tiger shrimp at the end of the experiment

\begin{tabular}{|c|c|}
\hline $\begin{array}{c}\text { Perlakuan (Treatments) } \\
\text { Wakt u aplikasi probiotik } \\
\text { Times of probiotik application }\end{array}$ & $\begin{array}{l}\text { Sint asan } \\
\text { Survival rate (\%) }\end{array}$ \\
\hline $\begin{array}{l}\text { A = Aplikasi probiotik pada awal hingga akhir penelitian (From } \\
\text { the beginning to the end of the experiment) }\end{array}$ & $43.3^{b c}$ \\
\hline $\begin{array}{l}\mathrm{B}=\text { Aplikasi probiotik pada minggu ke II hingga akhir pe nelitian } \\
\text { (From the seconds week to the end of the experiment) }\end{array}$ & $66.7^{a b}$ \\
\hline $\begin{array}{l}\mathrm{C}=\text { Aplikasi probiotik pada minggu ke IV hingga akhir penelitian } \\
\text { (From the fourth week to the end of the experiment) }\end{array}$ & $70.0^{\mathrm{a}}$ \\
\hline $\begin{array}{l}\mathrm{D}=\text { Aplikasi probiotik pada minggu ke-VI hingga akhir pe nelitian } \\
\text { (From the sixth week to the end of the experiment) }\end{array}$ & $40.0^{c}$ \\
\hline $\begin{array}{l}\mathrm{E}=\text { Aplikasi probiotik pada minggu ke VIII hingga akhir penelitian } \\
\text { (From the eighth week to the end of the experiment) }\end{array}$ & $48.9^{\mathrm{abc}}$ \\
\hline $\begin{array}{l}\mathrm{F}=\text { Aplikasi probiotik pada minggu ke } \mathrm{X} \text { hingga akhir pe nelitian } \\
\text { (From the tenth week to the end of the experiment) }\end{array}$ & $41.1^{\mathrm{bc}}$ \\
\hline $\mathrm{G}=\mathrm{Kontrol}$ (Control)/Without probiotic) & $34.6^{\mathrm{c}}$ \\
\hline
\end{tabular}


windu mencapai 81,3\%-93,3\% (Muliani et al., 2008a).

Hasil analisis statistik menunjukkan bahwa sintasan udang windu pada perlakuan C (aplikasi probiotik pada minggu ke-IV sampai akhir penelitian) berbeda nyata $(P<0,05)$ dengan perlakuan lainnya kecuali dengan perlakuan B (aplikasi probiotik pada minggu ke-Il sampai akhir penelitian). Dari data tersebut menunjukkan bahwa pemberian probiotik pada minggu ke-II dan minggu ke-IV setelah penebaran memberi efek yang lebih baik terhadap sintasan udang windu. Hal ini diduga disebabkan jika pemberian probiotik terlalu cepat sementara kualitas air masih dalam keadaan normal maka efek probiotik tersebut belum kelihatan, demikian pula jika pemberian probiotik terlambat maka kualitas air sudah terlanjur memburuk sehingga pemberian probiotik tidak berdampak lagi. Hal ini dapat dilihat dari data total bakteri dalam air pada perlakuan $\mathrm{C}$ relatif lebih tinggi dibanding dengan perlakuan lainnya, bahkan berbeda nyata dengan perlakuan D dan G, sementara total Vibrio spp. dan nilai kualitas air yang dianggap berbahaya relatif lebih rendah. Kondisi seperti ini memberi kontribusi pada peningkatan sintasan pasca larva udang windu pada perlakuan tersebut.

\section{KESIMPULAN}

- Tingginya total bakteri dalam air dan sedimen pada perlakuan yang diberi probiotik mulai minggu ke-IV hingga akhir penelitian berbanding terbalik dengan total Vibrionya.

- Kosentrasi BOT, $\mathrm{NH}_{4}-\mathrm{N}$, dan $\mathrm{NO}_{2}-\mathrm{N}$ pada perlakuan aplikasi probiotik mulai minggu ke-IV hingga akhir penelitian relatif lebih rendah dibanding perlakuan lainnya.

- Tingginya sintasan udang windu pada perlakuan yang diberi probiotik pada minggu ke-IV sampai dengan akhir penelitian $(\mathrm{P}<0.05)$ membuktikan bahwa bakteri probiotik tersebut mampu menekan bakteri Vibrio spp.

\section{UCAPAN TERIMA KASIH}

Kepada rekan-rekan peneliti dan teknisi baik yang terlibat langsung maupun tidak, diucapkan terima kasih yang setinggitingginya atas terlaksananya penelitian ini. Penelitian ini dibiayai oleh APBN T/A 2008 dengan judul kegiatan "Riset Budidaya Udang
Windu", sub kegiatan "Pencegahan penyakit udang windu melalui penggunaan bakteri probiotik".

\section{DAFTAR ACUAN}

Albaladejo, J.D., Tapay, L.M., Migo, V.P., Alfafara, C.G., Somga, J.R., Mayo, S.L., Miranda, R.C., Natividal, K., Magbanua, F.O., Itami, T., Matsumura, M., Nadala, E.C.B., \& Loh, P.C. 1998. Screening for shrimp viruses in the Philippines. In Flegel TW. (Ed.). Advances in shrimp biotechnology. National Center for Genetic Engineering and Biotechnology, Bangkok, p. 252-253.

Balcazar, J.L., Vendrell, D., Blas, I D., Zarzuela, I.R., Muzquiz, J.L., \& Girones, O. 2008. Characterization of probiotic properties of lactic acid bacteria isolated from intestinal microbiota of fish. Aquaculture, 278: 188191.

Banerjee, S., Devaraja, T.N., Shariff, M., \& Yusoff, F.M. 2007. Comparison of four antibiotics with indigenous marine Bacillus spp. in controlling pathogenic bacteria from shrimp and artemia. Journal of Fish Diseases, 30: 383-389.

Brunt, J. \& Austin, B. 2005. Use of a probiotic to control lactococcosis and streptococcosis in rainbow trout, Oncorhynchus mykiss (Walbaum). Journal of Fish Diseases, 28: 693701.

Brunt, J., Fyzul, A.N., \& Austin, B. 2007. The development of probiotics for control of multiple bacteria diseases of rainbow trout, Oncorhynchus mykiss (Walbaum). Journal of Fish Diseases, 30: 573-579.

Castex, M., Chim, L., Pham, D., Lemaire, P., Wabete, N., Nicolas, J.L., Schmidely, P., \& Mariojouls, C. 2008. Probiotic P. acidilactici application in shrimp Litopenaeus stylirostris culture subject to vibriosis in New Caledonia. Aquaculture, 275: 182-193.

Chabrillon, M., Arijo, S., Rosales, P.D., Balebona, M.C., \& Morinigo, M.A. 2006. Interferente of Listonelle anguillarum with potential probiotic microorganisms isolated from farmed gilthead seabream (Sparus aurata, L.). Aquaculture Research, 37: 78-86.

Decamp, O., Moriaty, D.J.W., \& Lavens, P. 2008. Probiotics for shrimp larviculture: review of field data from Asia and Latin America. Aquaculture Research, 39: 334-338.

Devaraja, T.N., Yusoff, F.M., \& Shariff, M. 2002. Changes in bacterial populations and 
shrimp production in ponds treated with commercial microbial products. Aquaculture, 206: 245-256.

Dhar, A.K., Roux, M.M., \& Klimpel K.R. 2001. Detection and quantification of infectious hypodermal and hematopoietic necrosis virus and White Spot Syndrome Virus in shrimp using real-time quantitative PCR and SYBR gereen chemistry. Journal of Clinical Microbiology, 39: 2,835-2,845.

Ghosh, S., Sinha, A., \& Sahu, C. 2007. Effect of probiotic on reproductive performance in female livebearing ornamental fish. Aquaculture Research, 38: 518-526.

Gunarto, Tangko, A.M., Tampangallo, B.R., \& Muliani. 2006a. Budidaya udang windu (Penaeus monodon) di tambak dengan penambahan probiotik. J. Riset Akuakultur, 1: 303-313.

Gunarto, Muslimin, Muliani, \& Sahabuddin. 2006b. Analisis kejadian serangan White Spot Syndrome Virus (WSSV) dengan beberapa parameter kualitas air pada budidaya udang windu menggunakan sistem tandon dan biofilter. J. Riset Akuakultur, 1: 255-270.

Hala, Y. 1999. Penggunaan gen penanda molekular untuk deteksi pelekatan dan kolonisasi vibrio harveyi pada larva udang windu (Penaeus monodon). Disertasi. Bogor. Institut Pertanian Bogor, Program Pascasarjana, $91 \mathrm{hlm}$.

Haryanti, Sugama, K., Tsamura, S., \& Nishijima, T. 2000. Vibriostatic bacterium isolated from seawater: Potentiality of probiotic agent in the rearing of Penaeus monodon larvae. Ind. Fish. Res. J., 6: 26-32.

Keysami, M.A., Saad, C.R., Sijam, K., Daud, H.M., \& Alimon, A.R. 2007. Effect of Bacillus subtilis on growth development and survival of larvae Macrobrachium rosenbergii (de Maan). Aquaculture Nutrition, 13: 131136.

Kono, T., Savan, R., \& Itami, T. 2004. Detection of white spot syndrome virus in shrimp by loop-mediated isothermal amplification. J. Virol. Methods; 115: 59-65.

Kumar, R., Mukherjee, S.C., Prasad, K.P., \& Pai, A.K. 2006. Evaluation of Bacillus subtilis as a probiotic to Indian major carp Labeo rohita (Ham.). Aquaculture Research, 37: 1,2151,221 .

Li, J., Tan, B., Mai, K., Ai, Q., Zhang, W., Xu, W., Liufu, Z., \& Ma, H. 2006. Comparative study between probiotic bacterium Arthrobacter XE-7 and chloramphenicol on protection of Penaeus chinensis post-larvae from pathogenic vibrios. Aquaculture, 253: 140147.

Lio-Po, G.D., Leoano, E.M., Penaranda, M.M.D., Villa-Franco, A.U., Sombito, C.D., \& Guanson, N.G. 2005. Anti-luminous Vibrio factors associated with the 'green water' grow-out culture of the tiger shrimp Penaeus monodon. Aquaculture, 250: 1-7.

Loh, P.C., Cesar, E., Nadala,J.R.B., Tapay, L.M., \& Lu, Y. 1998. Recent developments in Immunologically-Based and cell culture protocols for the specific detection of shrimp viral pathogen. In Flegel TW. (Ed.). Advances in shrimp biotechnology. BIOTEC. The National Center for Genetic Engineering and Biotechnology, Bangkok, Thailand, p. 255-259.

Macey, B.M. \& Coyne, V.E. 2005. Improve growth rate and resistance in farmed Haliotis midae through probiotic treatment. Aquaculture, 245: 249-261.

Makridis, P., Martins, S., Reis, J., \& Dinid, M.T. 2008. Use of probiotic bacteria in the rearing of Senegalese sole (Solea senegalensis) larvae. Aquaculture Research, 39: 627-634.

Meunpol, O., Lopinyosiri, K., \& Menasveta, P. 2003. The effects of ozone and probiotics on the survival of black tiger shrimp (Penaeus monodon). Aquaculture, 220: 437448.

Muliani, Suwanto, A., \& Hala, Y. 2003. Isolasi dan karakterisasi bakteri asal laut Sulawesi untuk biokontrol penyakit vibriosis pada larva udang windu (Penaeus monodon Fab.). Hayati, 10: 6-11.

Muliani, Nurbaya, Tompo, A., \& Atmomarsono, M. 2004. Eksplorasi bakteri filosfer dari tanaman mangrove sebagai bakteri probiotik pada budidaya udang windu Penaeus monodon. J. Pen. Perik. Ind., 2: 4757.

Muliani, Nurbaya, \& Tompo, A. 2005. Pengaruh jenis dan konsentrasi bakteri probiotik terhadap kualitas air dan sintasan pascalarva udang windu yang dipapar dengan White Spot Syndrome Virus (WSSV). dalam Subagja, J., Samiarti, E., Kasiamdari, R.S., Pratiwi, R., Nuringtyas, T.R. (Eds.). Prosiding Seminar Nasional dan Kongres Bilogi XIII Dalam Rangka Luxtrum X, 
Fakultas Biologi Universitas Gajah Mada. Yogyakarta.

Muliani, Nurbaya, \& Atmomarsono, M. 2006. Penapisan bakteri yang diisolasi dari tambak udang sebagai kandidat probiotik pada budi daya udang windu, Penaeus monodon. J. Riset Akuakultur, 1: 73-85.

Muliani, Susianingsih, E., \& Nurbaya. 2007. Perubahan kualitas air dan sintasan udang windu (Penaeus monodon) dalam laboratorium yang ditritmen dengan bakteri probiotik dengan komposisi jenis dan kepadatan yang berbeda. Dalam Achmad, T., Haryanti, Giri, N.A., Sumiarsa, G., Rachmansyah, Insan, I. (Eds.). Pengembangan Teknologi Budidaya Perikanan. Balai Besar Riset Perikanan Budidaya Laut. Badan Riset Kelautan dan Perikanan, p. 286-294.

Muliani, Nurbaya, \& Madeali, M.I. 2008a. Total bakteri, Vibrio spp., Sulfat Reduction Bacteria (SRB), dan Sulfur Oxidazing Bacteria (SOB) dalam wadah pemeliharaan udang windu dengan pemberian bakteri probiotik sistem bergilir. Dalam Litaay, M., Fachruddin, Sukendarsi, E., Zulkifli, A. (Eds.). Prosiding Seminar Nasional Biologi XIX. Makassar 9-10 Juli 2008, hlm. 134-139.

Muliani, Nurbaya, \& Tampangallo, B. R. 2008b. Pengaruh rasio bakteri probiotik terhadap perubahan kualitas air dan sintasan udang windu, Penaeus monodon dalam akuarium. J. Riset Akuakultur, 3: 33-42.

Nejad, S.Z., Resaei, M.H., Takami, G.A., Lovett, D.L., Mirvaghefi, A.R., \& Shakouri, M. 2006. The effect of Bacillus spp. bacteria used as probiotics on digestive enzyme activity, survival and growth in the Indian white shrimp Fenneropenaeus indicus. Aquaculture, 252: 516-524.

Nogami, K. \& Maeda, M. 1992. Bacteria as biocontrol agents for rearing larvae of the crab Portunus triberculatus. J. Fish. Aquat. Sci., 49: 2,373-2,376.

Nurbaya, Nurhidayah, Muliani, \& Atmomarsono, M. 2007a. Pengaruh jenis dan konsentrasi bakteri probiotik terhadap perubahan kualitas air dan sintasan udang windu yang dipapar dengan Vibrio harveyi. Dalam Achmad, T., Haryanti, Giri, N.A., Sumiarsa, G., Rachmansyah, Insan, I. (Eds.). Pengembangan Teknologi Budidaya Perikanan. Balai Besar Riset Perikanan Budidaya Laut. Badan Riset Kelautan dan Perikanan, hlm. 34-41.
Nurbaya, Nurhidayah, Muliani, \& Madeali, M.I. 2007b. Pengaruh perbedaan komposisi bakteri probiotik terhadap kualitas air dan sintasan udang windu (Penaeus monodon). Dalam Purnomo, Fajar, M., Yaniharto, D., Febriani, M., Sudaryono, A. (Eds.). Prosiding seminar Aquaculture Indonesia 2007. Surabaya, hlm. 62-67.

Pasharawipas, T., Sriurairatana, S., Direkbusarakom, S., Donayadol, Y., Thaikua, S., Ruangpan, L., \& Flegel, T.W. 1998. Luminous Vibrio harveyi associated with tea brown gill syndrome in black tiger shrimp. In Flegel TW. (Ed.). Advances in shrimp biotechnology. BIOTEC. The National Center for Genetic Engineering and Biotechnology, Bangkok, Thailand, p. 213-216.

Peng, S.E., Lo, C.F., Lin, S.C., Chen, L.L., Chang, Y.S., Liu, K.F., Su, M.S., \& Kou, G.H. 2001. Performance of WSSV-infected and WSSVnegative Penaeus monodon postlarvae in culture ponds. Dis. Aquat. Org., 46: 165172.

Poernomo, A. 2004. Technology of probiotics to solve the problems in shrimp pond culture and the culture environment. Paper presented in the National Symposium on on Development and Scientific and Technology Innovation in Aquaculture, Semarang, January 27-29, 2004, 24 pp.

Radjasa, O.K., Martens, T., Grassart, H.P., Sabdono, A., Simon, M., \& Bachtiar, T. 2005. Antibacterial property of a coral-associated bacterium Pseudoalteromonas luteoviolcea against shrimp pathogenic Vibrio harveyi (In vitro study). Hayati, 12: 71-81.

Rengpipat, S., Rueangruklikhit, T., \& Piyatiratitivorakul, S. 2008. Evaluations of lactic acid bacteria as probiotics for juvenile seabass Lates calcarifer. Aquaculture Research, 39: 134-143.

Rodriguez, J., Bayot, B., Amano, Y., Panchana, F., de Blas, I., Alday, V., \& Calderon, J. 2003. White spot syndrome virus infection in culture Penaeus vannamei (Boone) in Ecuador with emphasis on histopathology and ultrastructure. J Fish Dis., 26: 439-450.

Rosa, D., Zafran, Tufik, I, \& Girsang MA. 1997. Pengendalian Vibrio harveyi secara biologis pada larva udang windu (Penaeus monodon): I. Isolassi Bakteri Penghambat. J. Pen. Perik. Indonesia, 3: 1-10.

Ruangpan, L. 1998. Luminous bacteria associated with shrimp mortality. In Flegel, T.W. (Ed.). Advances in shrimp biotechnology. 
National Center for Genetic Engineering and Biotechnology, Bangkok, Thailand, p. 205-211.

Spann, K.M., Vickers, J.E., \& Lester, R.J.G. 1995. Lymphoid organ virus of Penaeus monodon from Australia. Dis. Aquat. Org., 23: 127134.

Steel, R.G.D. \& Torrie, J.H. 1981. Principles and procedures of statistics. A biometrical approach ( $2^{\text {nd }}$ edition). International Student Edition. McGraw-Hill International Book Company, 633 pp.

Sugita, H., Ohta, K., Kuruma, A., \& Sagesaka, T. 2007. An antibacterial effect of Lactococcus lactis isolated from the intestinal tract of the amur catfish, Silurus asotus Linnaeus. Aquaculture Research, 38: 1,0021,004 .

Sukhumsirichart, W., Wongteerasupaya, C., Boonsaeng, V., Panyim, S., Sriurairatana, S., Withyachumnarnkul, B., \& Flegel, T.W. 1998. Genome organization and detection of Hepatopancreatic Parvovirus (HPV) from Penaeus monodon in Thailand. In Flegel, T.W. (Ed.). Advances in shrimp biotechnology. BIOTEC. The National Center for Genetic Engineering and Biotechnology, Bangkok, Thailand, p. 261-262.

Sanchez-Martinez, J.G., Aguirre-Guzman, G., \& Mejia-Ruiz, H. 2007. White Spot Syndrome Virus in cultured shrimp: A review. Aquaculture, 38: 1,339-1,354.

Susanto, B., Setyadi, I., Syahidah, D., Marzuqi, M., \& Rusdi, I. 2005. Penggunaan bakteri probiotik sebagai kontrol biologi dalam produksi massal benih rajungan (Portunus pelagicus). Jurnal Penelitian Perikanan Indonesia, 11:15-23.

Suzer, C., Coban, D., Kamaci, H.O., Saka, S., \& Firat, K. 2008. Lactobacillus spp. bacteria as probiotics in gilthead sea bream (Sparus aurata, L.) larvae: Effect on growth performance and digestive enzyme activities. Aquaculture, 280: 140-145.
Tjahjadi, M.R., Angka, S.L., Suwanto, A. 1994. Isolation and evaluation of marine bacteria for biocontrol of luminous bacterial diseases in tiger shrimp larvae (Penaeus monodon Fab.). Aspac. J. Mol. Biol. Biotechnol. 2: 347-352.

Vaseeharan, B. \& Ramasamy, P. 2003. Control of pathogenic Vibrio spp. by Bacillus subtilis BT23, a possible probiotic treatment for black tiger shrimp Penaeus monodon. Lett. Appl. Microbiol, 36: 83-87.

Vaseeharan, B., Jayakumar, R., \& Ramasamy, P. 2003. PCR-base detection of White Spot Syndrome Virus in cultured and captured crustaceans in India. Lett. Appl. Microbiol., 37: 443-447.

Vaseeharan, B., Lin, J., \& Ramasamy, P. 2004. Effect of probiotics, antibiotic sensitivity, pathogenicity, and plasmid profiles of Listonella anguillarum-like bacteria isolated from Penaeus monodon culture system, Aquaculture, 241: 77-91.

Vijayan, K.K., Singh, I.S.B., Jayaprakash, N.S., Alavandi, S.V., Pai, S.S., Preeta, R., Rajan, J.J.S., \& Santiago, T.C. 2006. A brackishwater isolate of Pseudomonas PS-102, a potential antagonistic bacterium against pathogenic vibrios in penaeid and non-penaeid rearing systems. Aquaculture, 251: 192200.

Villamil, I., Firgueras, A., Planas, M., \& Novon, B. 2003. Control of Vibrio alginolyticus in artemia culture by treatment with bacterial probiotics. Aquaculture, 21 9: 43-56.

Wang, Y.B., Tian, Z.Q., Yao, J.T., \& Li, W.F. 2008. Effect of probiotics, Enteroccus faecium, on tilapia (Oreochromis niloticus) growth performance and immune response. Aquaculture, 277: 203-207.

Waston, A.K., Kaspar, H., Lategan, M.J., \& Gibson, L. 2008. Probiotics in aquaculture: The need, principles and mechanisms of action and screening processes. Aquaculture, 274: 1-14. 